\title{
Effect of water regime, pruning system and potassium silicate on dry mass production of sweet pepper plants grown in calcareous soil under greenhouse
}

\author{
Kotb H.M.- Hegazi H.H.- Ghoneim I.M.And M.N. Feleafel \\ Dep. of vegetable crops, Faculty of Agriculture \\ Alexandria University.
}

BSTRACT

Two greenhouse experiments were carried out at Army Farm, at El-Amria region, Alexandria, Egypt, during the two seasons of 2016-2017 and 2017-2018, as an attempt to rationalize of irrigation water through studying the effect of three water regimes, three pruning systems and four potassium silicate rates on the dry mass accumulation in the various plant organs of sweet pepper. Results showed that application of the lower amount of irrigation water (30\% depletion ratio) with repeat its addition achieved the highest significant mean values of roots, stems, leaves and whole plant dry mass at one, three and nine months after transplanting (MAT), as well as fruits dry mass after three and nine MFT, in the two seasons. Furthermore, the results indicated that un-pruned sweet pepper plants achieved significant higher mean values of roots, stems and whole plant dry mass, at three and nine MAT, in both seasons, as well as fruits dry mass at nine MAT only, in both seasons. The addition of, foliar application of potassium silicate up to 500 or $1000 \mathrm{mg}^{-1}$, significantly, accumulated higher dry weight in roots, branches, leaves, fruits and whole plant of sweet pepper plants after one, three and nine MAT, compared with that unsprayed, in the two seasons. Likewise, sweet pepper plants that un-pruned or pruned up to 3 branches plant ${ }^{-1}$ and irrigated with the lower amount of irrigation water (30\% depletion ratio) achieved the highest values of the dry mass of branches, leaves, fruits and whole plant at one, three and nine MAT compared with that pruned on two branches plant-1. However, the highest dry mass value of roots, branches, leaves, fruits and whole plant of pepper were obtained from the treatment combination included the lower amount of water (30\% water depletion ratio) and spray $1000 \mathrm{mg}^{-1}$ of potassium silicate, in both seasons, after one, three and nine MAT. Interactions between pruning systems and potassium silicate concentrations indicated that the highest values of the dry mass of roots, branches and whole plant of sweet pepper plants were achieved from treatment combinations containing un-pruned plants and sprayed the plants with $1000 \mathrm{mg} \mathrm{l}^{-1}$ of potassium silicate, in both seasons.

\section{Key word: Sweet pepper, Water, Regime, Pruning system,potassium Silicate, Dry mass}

\section{INTRODUCTION}

Sweet pepper (Capsicum annum L.) is one of the important Solanaceious vegetable crops that grown under greenhouses of worldwide. In Egypt, greenhouse pepper production is based on ninemonth cycle (El- Sayed et al., 2015), thus, it is a high-value cash crop that either for domestic market are for export.

The whole cycle of a sweet pepper plants divided into a vegetative and generative phases (Nielsen and Veierskov, 1988). In the vegetative growth stage, until 60 days after transplanting, the dry matter is oriented to the roots and leaves (Fernand, et al., 2004). While in the generative stage, it consumes in formation the flowers, stems, leaves, and fruits. Therefore, the challenge facing greenhouse sweet pepper producers is to establish a strong vegetative growth and production of extra-large-sized fruits for export. However, pepper plants have a relatively a small root system where does not exceed 19.4-8.6\% of the plant dry mass in both of the vegetative and reproductive growth stages, orderly (Fernand et al.,
2004). Consequently, it is important to know how to achieve a balance between the growth of both roots and formation of the stems, leaves, flowers, and fruits of the pepper plant, through the redistribution of dry matter among various plant organs by improving pruning system and foliar application of potassium silicate under water stress conditions.

Total water requirements of sweet pepper are $1250 \mathrm{~mm}$ for long growing seasons and several pickings (FAO, 2015), i.e. $5000 \mathrm{~m}^{3} \mathrm{fed}^{-1}$. For high yields, an adequate water supply and relatively moist soils are required during the growing period. The period at the beginning of the flowering is most sensitive to water shortage and soil water depletion in the root zone during this period should not exceed $25 \%$ (FAO, 2015). Water shortage just prior to and during early flowering reduces the number of fruit (Katerji et al., 1993 and FAO, 2015). Therefore, controlled irrigation is essential for high yields because the crop is sensitive to both over and under irrigation (FAO, 2015). Where, Hedge (1987) found that bell pepper yields in India were similar when 
irrigated at $40 \%$ and $60 \%$ of available soil moisture, but yields were reduced when irrigation was applied at either $20 \%$ or $80 \%$ of available soil moisture.

Pruning system of sweet pepper plant is a tool to control of fruits development through restricting the branching pattern to 2 or 3 or 4 main stems. In this context, the limitation of shoot numbers achieved the heavier fruits (Cebula, 1995, Jovicich, et al., 1999, Maboko et al., 2012 and Alsadon et al., 2013). Whereas, decreasing the number of shoots of pepper reduced the number of leaves on the plants, while the surface of a single leaf was extended (Dasgan and Abak, 2003), therefore this leads to a balance between vegetative and reproductive growth in order to maximize plant growth and fruit production. Where, pruning system contributes to facilitate the light penetration of the leaves, improve fruit set, early fruit ripening, and high yield of largesized fruits (Resh, 1996, Jovicich, et al., 1999 and Zende, 2008). Moreover, it achieves saving in the amount of water irrigation through reducing plant leaf area and canopy (Hipps et al., 2014). Awalin et al. (2017) found that shoot pruning of pepper achieved the greatest number of marketable fruits per plant (8.70), maximum fruit setting (39.32\%) and highest yield (26.60 t/ha).

Silicon (Si) foliar application, as potassium silicates, is a relatively new technique of feeding the plants. Where, Si has many roles in the plant physiology; regulation of the uptake of other ions and increase tolerance plants to various biotic and abiotic stresses (Zhu et al., 2004) as well as alleviate water stress through reduce transpiration rate (Hattori et al., 2005) by reduction the diameter of stomatal pores (Efimova and Dokynchan, 1986). Si is stimulating the growth and development of many plant species by correcting the levels of endogenous growth hormones, i.e., auxins, gibberellins and cytokinins under stress conditions (Hanafy Ahmed et al., 2008). Moreover, the adequate nutrition with Si interferes in the plant architecture; by enhancing rigidity, strengthening and elasticity of cell wall (Hanafy Ahmed et al., 2008) as well as improving erecting of leaves, increasing solar radiation interception and photosynthetic efficiency (Pereira et al., 2003; Al-Aghabary et al., 2004).

The current research was carried out as an attempt to achieve a balance between both the vegetative growth and fruits production by studying the influence of three-irrigation water regime, three pruning systems and four potassium silicate rates as well as its interactions on the dry mass production of sweet pepper plants (Gavotte F1 cv.) grown in calcareous soils under greenhouse.

\section{MATERIALS AND METHODS}

Two greenhouse experiments were carried out at the Army Farm, in El-Amria region, Alexandria, Egypt, during the two seasons of 2016-2017 and 2017-2018, as an attempt to rationalize of irrigation water through following up the distribution of dry mass in the various plant organs of sweet pepper, as affected by threeirrigation water regime, three pruning systems and four potassium silicate rates. Each experiment was conducted in nine greenhouses; the area of each greenhouse was $360 \mathrm{~m}^{2}(6$ rows $\times 1.5 \mathrm{~m}$ width $\times 40 \mathrm{~m}$ long).

One week before pepper transplanting, $4 \mathrm{~m}^{3}$ of cattle manure $+2 \mathrm{~m}^{3}$ of chicken manure $+20 \mathrm{~kg}$ sulfur $+50 \mathrm{~kg}$ calcium super phosphate $15.5 \%$ was incorporated into the soil of the six rows, in each greenhouse, at $15-20 \mathrm{~cm}$ depth.

Preceding the initiation of each experiment, in both seasons, soil samples were collected from nine greenhouses, at $15-30 \mathrm{~cm}$ depth, and analyzed in Nobariya Lab. of agricultural analyses, for some soil's physical and chemical properties according to the published procedures (Page et al., 1982), the results of this analyses are listed in Table (1).

In each greenhouse, the drip irrigation network consisted of lateral's GR of $16 \mathrm{~mm}$ in diameter, with emitters at $0.5 \mathrm{~m}$ distance, with allocating two laterals for each row. The emitters had a discharge rate $4 \mathrm{l} \mathrm{h}^{-1}$. For good plant establishment, before transplanting, $5 \mathrm{~m}^{3}$ of irrigation water was applied to each greenhouse, and then the transplants of sweet pepper (Gavotte F1 cv., Rijk Zwaan Co., Netherlands) were sown, on August $5^{\text {th }}$, in both seasons of 2016 and 2017, in two lines on each row. The row spacing was $50 \mathrm{~cm}$ between the transplants and $25 \mathrm{~cm}$ between the two lines.

\section{Treatments:}

\section{1-Water Regime}

Three water regime (based on depletion ratio) treatments were executed, in the two experiments; 30,50 and $70 \%$ from the available soil water (ASW) in the root zone. Therefore, net irrigation application depth to sandy loam soil was calculated to maintain the available soil water in the root zone ( up to $30 \mathrm{~cm}$ depth) at 30, 50 and $70 \%$ in accordance with a depletion ratio 70,50 and $30 \%$, according to a formula that reported by Qassim and Ashcroft (2002).

Net irrigation application depth $(\mathrm{mm})=$ Root depth $(\mathrm{m}) \times$ depletion fraction $\times$ total available water ( $\mathrm{mm} \mathrm{m}$-1) 
Table 1: some growing seasons physical and chemical properties of the experimental soil in 20162017 and 2017-2018.

\begin{tabular}{|c|c|c|c|c|c|c|c|c|c|c|c|c|c|c|c|c|c|c|c|c|c|c|}
\hline \multirow{2}{*}{$\begin{array}{c}\text { Season } \\
\mathrm{s}\end{array}$} & \multicolumn{4}{|c|}{$\begin{array}{c}\text { Mechanical } \\
\text { properties }\end{array}$} & \multirow{2}{*}{$\begin{array}{r}\text { Textur } \\
\text { e }\end{array}$} & \multicolumn{14}{|c|}{ Chemical properties } & \multicolumn{3}{|c|}{$\begin{array}{c}\text { Physical } \\
\text { properties }\end{array}$} \\
\hline & $\begin{array}{c}\text { Sand } \\
\%\end{array}$ & $\begin{array}{c}\text { Silt } \\
\% \%\end{array}$ & $\begin{array}{c}\text { Gravel } \\
\%\end{array}$ & $\begin{array}{l}\text { SP } \\
\%\end{array}$ & & $\begin{array}{c}\mathrm{EC} \\
\mathrm{dS} \mathrm{m}^{-} \\
1\end{array}$ & $\mathrm{pH}$ & $\begin{array}{c}\mathrm{Na}^{+} \\
\mathrm{mgl}^{-}\end{array}$ & $\begin{array}{l}\mathrm{Ca}^{++} \\
\mathrm{mgl}^{-1}\end{array}$ & $\begin{array}{l}\mathrm{Mg}^{++} \\
\mathrm{mgl}^{-1}\end{array}$ & $\begin{array}{l}\mathrm{HCO} \\
\mathrm{mgl}^{-3}\end{array}$ & $\underset{\mathrm{mgl}^{-1}}{\mathrm{CL}}$ & $\begin{array}{c}\mathrm{CO} \\
3 \\
\mathrm{mgl}^{-}\end{array}$ & SAR & $\begin{array}{c}\text { Caco3 } \\
\%\end{array}$ & $\begin{array}{c}\text { O.c } \\
\%\end{array}$ & $\begin{array}{c}\mathrm{OM} \\
\%\end{array}$ & $\begin{array}{c}\mathrm{P} \\
\mathrm{mgl} \\
-1\end{array}$ & $\begin{array}{c}\mathrm{K} \\
\mathrm{mgl}^{-1}\end{array}$ & $\begin{array}{l}\text { Virtual } \\
\\
\text { Density } \\
\mathrm{g} \mathrm{cm}-3 \\
\end{array}$ & $\begin{array}{c}\text { Porosity } \\
\% \\
\end{array}$ & $\begin{array}{c}\text { Field } \\
\text { Capacity } \\
\%\end{array}$ \\
\hline $\begin{array}{l}2016- \\
2017\end{array}$ & 44 & $34 \quad 22$ & 1.2 & 37 & $\begin{array}{l}\text { Sandy } \\
\text { loam }\end{array}$ & $\begin{array}{c}5.9 \\
7\end{array}$ & $\begin{array}{c}8.0 \\
4\end{array}$ & $\begin{array}{c}64 \\
0\end{array}$ & $\begin{array}{c}255 . \\
5\end{array}$ & $\begin{array}{c}116 . \\
6\end{array}$ & 188 & $\begin{array}{c}986 . \\
5\end{array}$ & 0 & $\begin{array}{c}4.14 \\
5\end{array}$ & 8.72 & $\begin{array}{l}.7 \\
5\end{array}$ & $\begin{array}{c}1.2 \\
0\end{array}$ & 1.7 & $\begin{array}{c}12 . \\
9\end{array}$ & 1.45 & 39.5 & 11.92 \\
\hline
\end{tabular}

However, the actual water use of the pepper (crop evapotranspiration; Etc.), under greenhouse at ElAmria region conditions, was calculated and adjusted at the beginning of each week throughout the growing season, about 43 weeks (From August until the end of May). It is calculated by multiplying reference evapotranspiration $\left(\mathrm{ET}_{0}\right)$ of El-Amria region, by a crop coefficient $\left(\mathrm{K}_{\mathrm{C}}\right) ; \mathrm{ET}_{\mathrm{c}}\left(\mathrm{mm}\right.$ day $\left.^{-1}\right)=\mathrm{ET}_{0} \times \mathrm{K}_{\mathrm{c}} \times$ 0.73, as indicated in Allen et al., 1998 and Razmi and Ghaemi (2011), Table (2). Addition, irrigation frequency (irrigation period) was calculated by dividing the net irrigation application depth $(\mathrm{mm})$ by $\mathrm{ET}_{\mathrm{c}}\left(\mathrm{mm}\right.$ day $\left.^{-1}\right)$.

Irrigation period (day) $=$ net irrigation application depth $(\mathrm{mm})$ ETC(mm day-1)

\section{Pruning systems}

Three pruning systems were executed on the sweet pepper plants that grown under greenhouse, where after 30 days from transplanting, the first crown flower and lateral shoots, just above the cotyledonary node, were removed. Based on the number of branches, which left on each plant of sweet pepper, the pruning treatments were; control without pruning (Spanish pruning), left 2 and 3 main branches plant ${ }^{-1}$ (Holland pruning).

\section{Potassium Silicate}

Potassium silicate $\left(\mathrm{K}_{2} \mathrm{SIO}_{3}\right)$, in a powder form, contain $22.5 \% \mathrm{SiO}_{2}$ and $10.25 \% \mathrm{~K}_{2} \mathrm{O}$, were used as a foliar application at four concentrations; 0, 250, 500 and $1000 \mathrm{mg} \mathrm{l}^{-1}$. Potassium silicate was sprayed four times, at 30, 60, 90, and 120 days after transplanting. Spreading agent (Super Film $1 \mathrm{ml} \mathrm{l}^{-1}$ ), was used, with different potassium silicate concentrations. The untreated plants (control) were sprayed with tap water plus the same spreading agent only.

\section{Experimental Design:}

Each experiment included 36 treatments, which were the combinations of four potassium silicate concentrations $\left(0,250,500\right.$ and $\left.1000 \mathrm{mg} \mathrm{l}^{-1}\right)$ under three pruning systems (without pruning, left 2 and 3 main branches plant ${ }^{-1}$ )under three water regimes (30, 50 and $70 \%$ from the available soil water). The experimental design used was the split-split-plot system in a Randomized
Complete Blocks Design, with three replications. Each replicate contained three greenhouses (main plots). Three water regime treatments were, randomly, arranged in the main plots, while three pruning systems were, randomly, distributed within each greenhouse as the sub-plots. Each sub-plot contained two rows having an area of $120 \mathrm{~m}^{2}$. Moreover, four potassium silicate concentrations were randomly distributed within each pruning system as sub-sub-plots. Each subsub-plot contained two rows having an area of 30 $\mathrm{m}^{2}$.The average temperatures and relative air humidity inside the greenhouse were $24.6 \pm 2.1^{\circ} \mathrm{C}$ and $50.2 \pm 2 \%$ throughout sweet pepper growth stages, respectively.

\section{Agricultural Practices}

All sub-sub-plots received the same amounts of fertilizers, where received $\mathrm{N}, \mathrm{P}$ and $\mathrm{K}$ fertilizers at the rates of $180-270-180 \mathrm{~kg} \mathrm{fed}^{-1}$ as ammonium nitrate $(33.5 \% \mathrm{~N})$, nitric acid $(55 \%)$, NPK compound fertilizer (19-19-19) and mono potassium phosphate (0-52-34), in both experiments. NPK fertilizers were injected directly into the irrigation water (fertigation) using a venture injector at two doses weekly, started in the $2^{\text {nd }}$ week after transplanting and continued up to the $39^{\text {th }}$ week. Other cultural practices such as pest control and cultivation were carried out, whenever; it was necessary and as applied to the greenhouse commercial sweet pepper production.

\section{Data Recorded:}

After one, three, and nine months from transplanting (MFT), five plants were randomly chosen, from each sub-sub-plot, then uprooted from the soil to determine the dry mass accumulation of the root, stem and leaves (g) per plant. Moreover, sweet pepper fruits were harvested at twice weekly starting from 90 days after transplanting, then at the end of the growing season; fruits yield per plant was recorded and the dry mass accumulation of fruits $(\mathrm{g})$ per plant were determined ( Ryan et al.,2007). 
Table 2: Length of the growth stages, crop coefficients $(\mathrm{Kc})$, reference evapotranspiration (ET0) and water requirements (ETc) of pepper plants growing under the greenhouse, as average to both seasons of 2016-2017 and 2017-2018 growing seasons.

Growth stages Vegetative Flowering and fruits End season formation

\begin{tabular}{lccc}
\hline Number of days stage $^{-1}$ & 35 & 235 & 30 \\
\hline Average crop coefficients $\left(\mathrm{K}_{\mathrm{C}}\right)$ & 0.65 & 1.0 & 0.95 \\
\hline Average reference evapotranspiration $\left(\mathrm{ET}_{0}\right) \mathrm{mm} \mathrm{day}^{-1}$ & 5.6 & 3.5 & 5.6 \\
\hline Water requirements of pepper crop $\left(\mathrm{ET}_{\mathrm{c}}\right) \mathrm{mm} \mathrm{day}$ & 3.64 & 3.5 & 5.32 \\
\hline Total water requirements per growth stage & 127.4 & 822.5 & 159.6 \\
\hline
\end{tabular}

Statistical Analysis:

Data recorded during the study were subjected to analysis of variance techniques according to the design used by the CoSTAT statistics software program. The Revised LSD test at $\mathrm{P}<0.05$ was used to compare differences among means of various treatment combinations as described by Gomez and Gomez (1983)..

\section{Results and discussion}

The results presented in Figures (1,2 and 3) showed significant influences of water regime (depletion ratios; 30,50 and $70 \%$ of ASW), pruning systems (without pruning, left 2 and 3 branches plant $\left.{ }^{-1}\right)$ and potassium silicate concentrations $\left(0,250,500\right.$ and $\left.1000 \mathrm{mg} \mathrm{l}^{-1}\right)$ on the dry mass accumulation of various plant organs of sweet pepper, through varied growth stages, i.e. after one, three and nine months after transplanting (MAT), in both seasons of 2016-2017 and 20172018.

Effect of Water Regime (depletion ratios)

Results in Figure 1 (B, C, E and F) illustrated that there were significant and gradual increases in dry mass accumulation of roots, branches, leaves, fruits, and whole plant through varied growth stages, i.e. at three and nine MAT, in both seasons, as a result of decreasing the water depletion ratio from 70 up to $30 \%$ of ASW in the root zone. the, application of lower amount of irrigation water (30\% depletion ratio) with repeat its addition achieved the highest significant mean values of roots, stems, leaves and whole plant dry mass at one, three and nine MAT, as well as fruits dry mass after three and nine MFT, in the two seasons of 2016-2017 and 2017-2018. Moreover, the results Figure 1 (A and D) showed that dry mass values of various plant organs of sweet pepper in the early growth stage ( at one MAT) did not significantly differ with applying irrigation water at $50 \%$ and $70 \%$ of ASW. While, significant difference between $50 \%$ and $70 \%$ of ASW were detected of dry mass values of various plant organs of sweet pepper after three and nine MAT, in both seasons. Such results might be expected on base that increase the available soil water, with the application of the lower amount of irrigation water (30\% depletion ratio) with repeat its addition, leads to growing sweet pepper plants with no exposure to any water stress. Accordingly, the increase in available soil water will led to an increase in available nutrients would allow for excessive rates of photosynthesis and the accumulation of stored food in the various plant organs of sweet pepper. The current results are in agreement to a great extent with those reported by Kirnak et al., (2001) who reported that plant growth is decreased when soil water availability is limited. Hedge (1987) found that bell pepper yields in India were similar when irrigated at $40 \%$ and $60 \%$ of available soil moisture, but yield was reduced when irrigation was applied at either $20 \%$ or $80 \%$ of available soil moisture. Moreover, Ezzo et al., (2010) revealed that moderate $\left(90 \% \mathrm{ET}_{0}\right)$ and medium $\left(70 \% \mathrm{ET}_{0}\right)$ irrigation regimes were able to compete high irrigation levels $\left(110 \%\right.$ of $\left.\mathrm{ET}_{0}\right)$ regarding the dry weight of sweet pepper plants. Likewise, Smittle et al. (1994) found that yields and water use were greatest when irrigation was applied at $25 \mathrm{kPa}$ than using 50, or $75 \mathrm{kPa}$ (Pressure unit kilopascal) during growing pepper crop.

Concerning the dry mass accumulation in branches, under the lower rate of depletion ratio $(30 \%)$, the results indicated that there were an increase in the dry weight of branches $15.60,60.80$ and 105.71 and 16.47, 56.52 and $101.65 \mathrm{~g}$ at one, three and nine MAT, in both seasons, respectively (Figure 1). Where, branches dry mass achieved 63.33 and $62.36 \%$ after one month, 57.60 and $53.26 \%$ after three months and 17.76 and $15.59 \%$ after 9 MAT from that accumulated by the whole plant, in two seasons. 

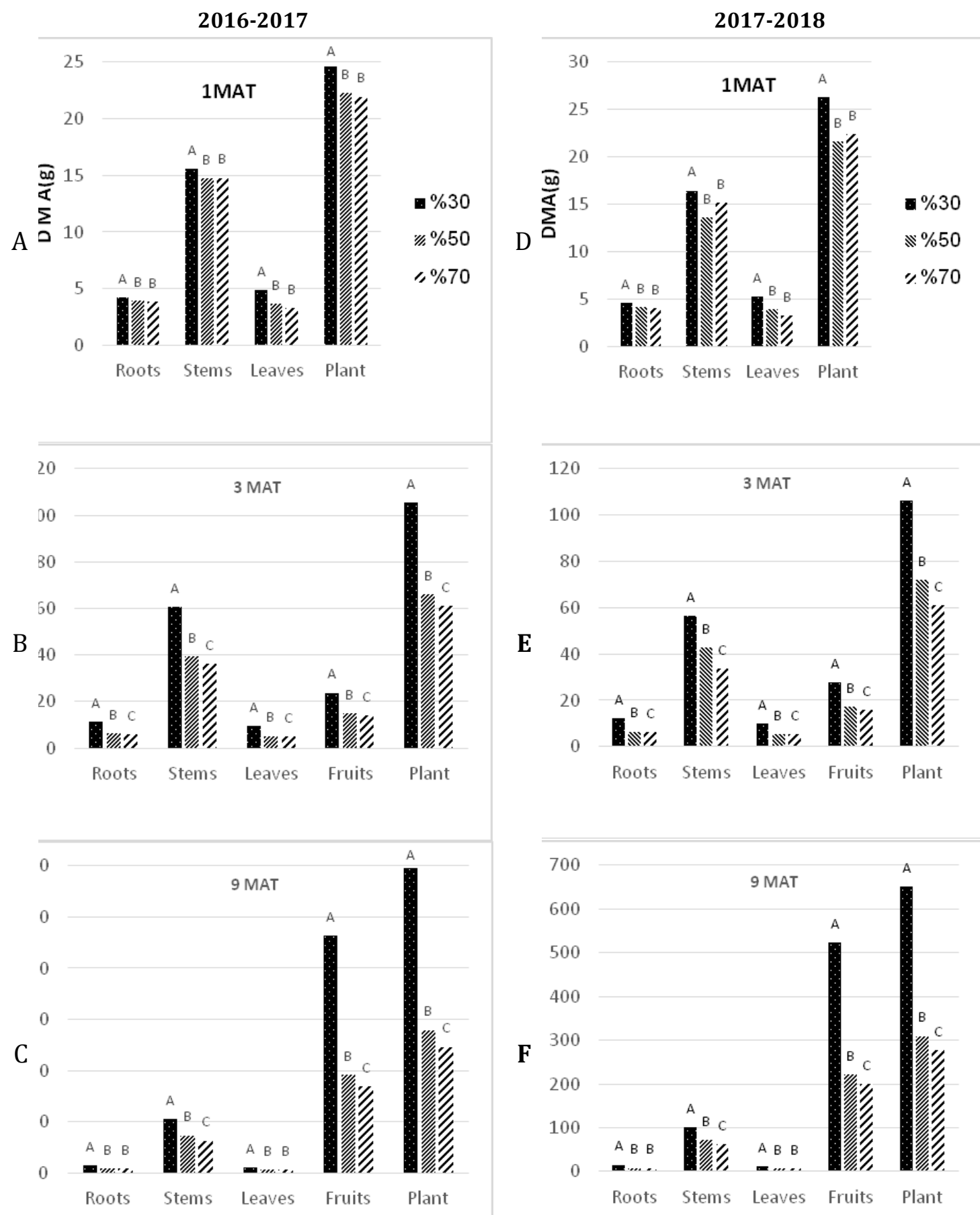

Fig. 1. Effects of water regime (depletion ratio \%) on the dry mass accumulation (DMA) throughout the varied growth stages of sweet pepper plant, in both seasons of 2016-2017 and 2017-2018.

A, B, C = after 1, 3 and nine months after transplanting (MAT), in season of 2016-2017.

$\mathrm{D}, \mathrm{E}, \mathrm{F}=$ after 1, 3 and nine months after transplanting (MAT), in season of 2017-2018. 

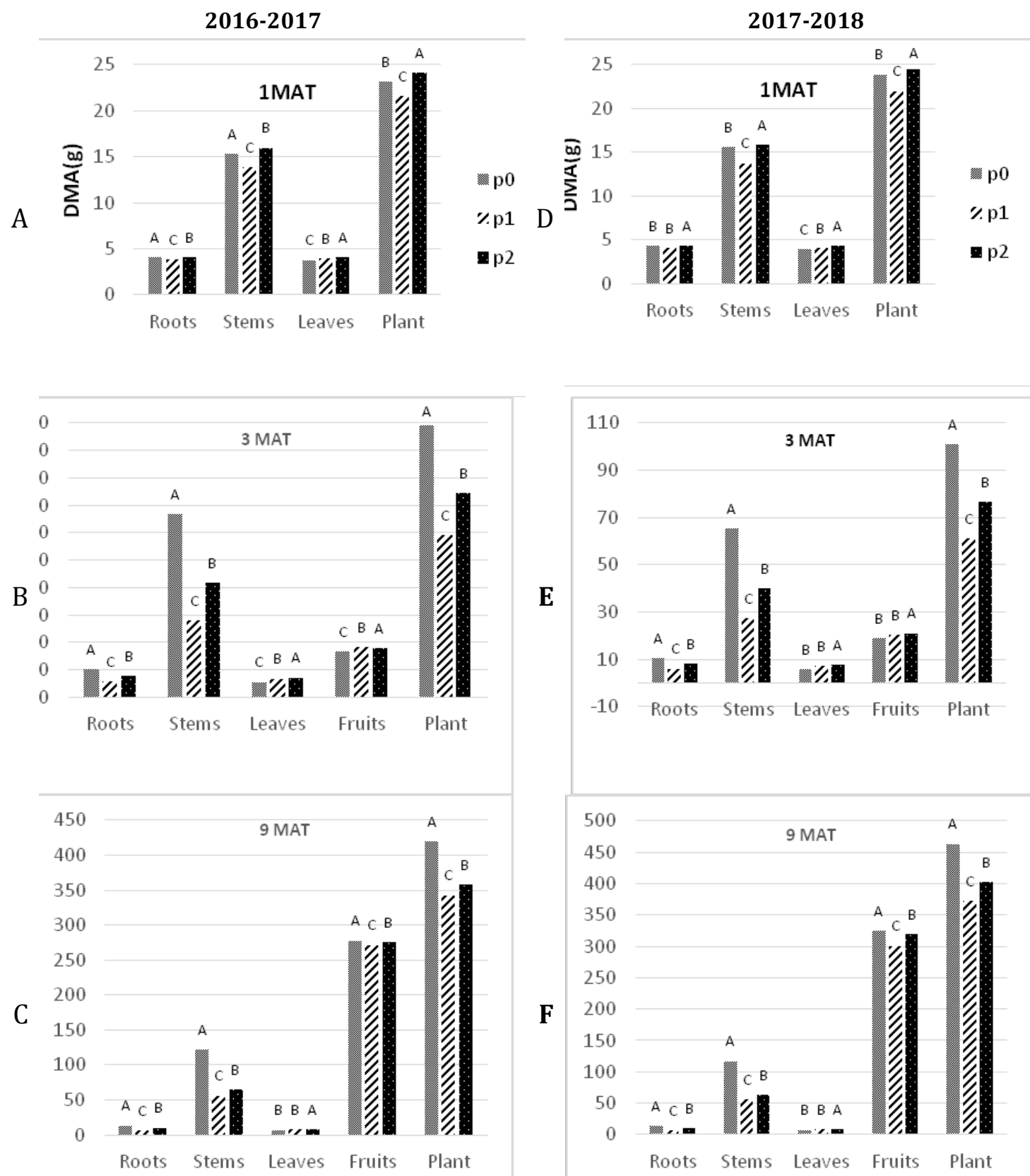

Fig. 2. Effects of pruning systems on the dry mass accumulation (DMA) throughout the varied growth stages of sweet pepper plant, in both seasons of 2016-2017 and 2017-2018.

A, B, C = after 1, 3 and nine months after transplanting (MAT), in season of 2016-2017.

$\mathrm{D}, \mathrm{E}, \mathrm{F}=$ after 1, 3 and nine months after transplanting (MAT), in season of 2017-2018. 


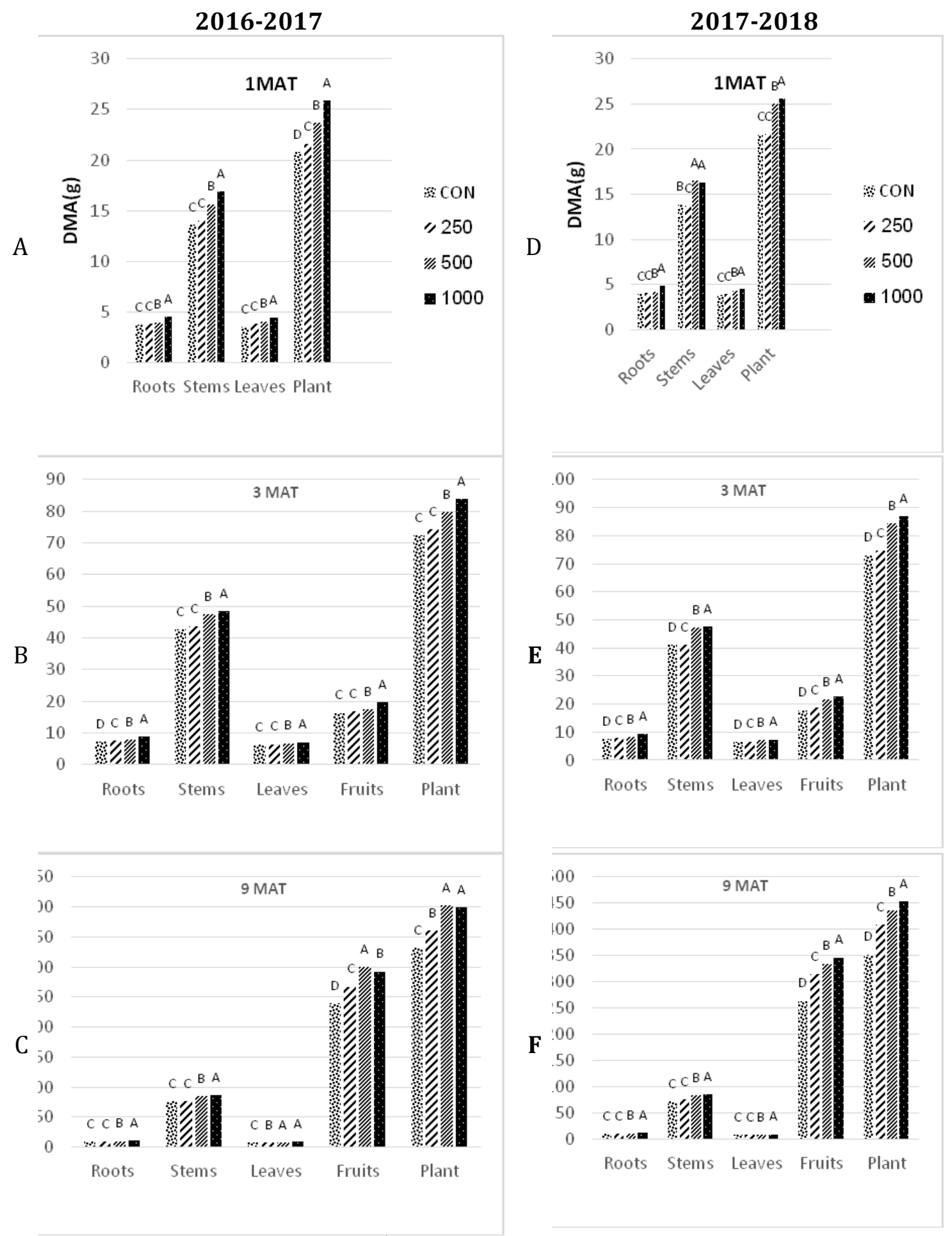

Fig. 3. Effects of potassium silicate $\left(\mathrm{mg} \mathrm{I}^{-1}\right)$ on the dry mass accumulation (DMA) throughout the varied growth stages of sweet pepper plant, in both seasons of 2016-2017 and 2017-2018.

A, B, C = after 1, 3 and nine months after transplanting (MAT), in season of 2016-2017.

$\mathrm{D}, \mathrm{E}, \mathrm{F}=$ after 1, 3 and nine months after transplanting (MAT), in season of 2017-2018. 
Regarding the fruits dry mass accumulation, the results in Figure (1) indicated that there were also, significant increase in the medium and late growth stages under the lowest depletion ratio $(30 \%)$. Where, fruits dry mass was recorded 23.78 \& 463.86 and $27.71 \& 523.39 \mathrm{~g}$ after three and nine MAT, which obtained 22.53 \& $26.08 \%$ after 3 MAT and $77.92 \& 80.24 \%$ after 9 MAT from the total dry mass accumulated by the whole plant under the same water depletion ratio in both seasons, respectively. These findings appeared to be in close agreement with results reported by Chatzoulakis and Drosos (1997) who indicated that application of 0.65 and $0.40 \times \mathrm{ET}_{\mathrm{m}}$ (based on maximum evapotranspiration) which equivalent to 384 and $296 \mathrm{~mm}$ of water gave significant reduction in plant dry weight. However, results of Vamez et al., (1992) reported that keeping the soil around field capacity $(-0.03 \mathrm{MPa})$, the plant dry weight significantly higher than those in more dry treatments (keeping soil water potential at -0.1 or $0.3 \mathrm{MPa}$ ).

\section{Effect of Pruning Systems}

Results in Figure 2 (A-F) indicated that there were a significant differences among pruning systems treatments on the dry mass accumulation of different sweet pepper plant organs at one, three and nine MAT, in both seasons. Spanish pruning system (un-pruned plants) for sweet pepper plants leads to accumulate more significant dry mass in the roots compared with Holland pruning system with 2 or 3 branches after one MAT, in the first season (Figure 2; D). Morovere, un-pruned sweet pepper plants achieved significant higher mean values of roots, stems and whole plant dry mass, at three and nine MAT, in both seasons (Figure 2; $\mathrm{B}, \mathrm{C}, \mathrm{E}$ and F), as well as fruits dry mass at nine MAT only, in both seasons(Figure 2; C and F). Generally, within the Holland pruning system, increasing the number of stems plant ${ }^{-1}$ from 2 to 3 branches, achieved the highest mean values of the roots, branches, leaves, fruits and whole plant dry mass at three and nine MAT, in the two growing seasons. Such a general positive response of dry mass accumulation of sweet pepper plants due to pruning system might be attributed to dry matter distribution is primarily regulated by the sinkstrength of the various organs. Thakur et al., (2018) stated that when the available assimilates equal or exceed the total sink strength of the plant, the growth rates of the vegetative parts and the individual fruit occur at the potential rates. However, when the amount of available assimilates is less than the total sink strength, the assimilates are distributed between roots, leaves, stem, and fruit according to their individual sink strengths relative to the total sink strength. Such results are in agreement with those obtained by Nielsen and Veierskov (1988) who mentioned that there is a balance development of the dry matter of roots and top, and a functional equilibrium seems to exist, but there seems to be an underlying control system of this balance. Jovicich, et al., (1999) reported that number and dry weight of leaves and total plant dry weight were higher in four and two than in singlebranche plants. Additionly, Maniutiu et al. (2010) reported that the shoot pruning is an important factor in proper utilization of production of sweet pepper. Furthermore, pruning of sweet pepper under greenhouse conditions facilitate light penetration throughout the leaf canopy for more efficient interception of light, which reflected on the increase the dry mass of the organs of sweet pepper plants (Jovicich, et al., 1999). The previous findings indicated that the foliar structure of the plants pruned to three main branches was sufficiently large to allow for higher accumulation of dry matter when compared with to the two branches within the Holland pruning system.

Effect of Potassium Silicate

The different comparisons, Figure 3 (A-F), indicated that, in both seasons, dry mass of the roots, branches, leaves, fruits and whole plant of sweet pepper plants grown in calcareous soil under greenhouse conditions increased significantly and successively as the concentration of potassium silicate was increased up to $1000 \mathrm{mg} \mathrm{l}^{-1}$ after one, three and nine MAT. Application of potassium silicate at concentration of $1000 \mathrm{mg} \mathrm{l}^{-1}$ produced the highest dry weight accumulation for all studied plant organs, at all growth stages, in the two seasons. These significant increases might be attributed to the favorable effect of potassium silicate on the plant metabolism, and due to improve erecting of leaves, increase solar radiation interception and photosynthetic efficiency, which reflected on the increase dry mass of sweet pepper plant organs as mentioned by (Pereira et al., 2003; Al-Aghabary et al., 2004).

Interaction Effects Between Water regime (Depletion Ratios) and Pruning Systems

It is obvious from the data presented in Table (3) that the first order interaction between water depletion ratios and pruning systems had significant effects on dry weight accumulation of roots, branches, leaves, fruits and whole plant of sweet pepper plants after one, three and nine MAT, in both seasons. In general, the best treatment combination, which achieved the highest mean values of the dry mass accumulation of roots, was that involved unpruned plants and irrigated with the lower amount of irrigation water (30\% depletion ratio) with repeat its addition. Meanwhile, sweet pepper plants that unpruned or pruned up to 3 branches plant ${ }^{-1}$ and irrigated with the lower amount of irrigation water (30\% depletion ratio) achieved the highest values of dry mass of branches, leaves, fruits and whole plant 
at one, three and nine MAT compared with that pruned on two branches plant ${ }^{-1}$. The increments in the dry mass of a pepper plants with combination between pruned pepper plants up to 3 branches and irrigated with the lowest amount of irrigation water (30\% depletion ratio), might be due to that pruning system contributes to facilitate the light penetration of the leaves. In addition to, the increase in available soil water will be led to an increase in available nutrients for excessive rates of photosynthesis.

Interaction Effects Between Water regime (Depletion Ratios) and potassium silicate concentrations

The statistical comparisons listed in Table (4) illustrated the presence of some interaction effects, between water regime and potassium silicate concentrations, on the dry mass accumulation in varied organs of sweet pepper plants, at one, three and nine MAT, in both growing seasons. The results showed that the highest dry mass accumulation of varied plant organs and whole plant were obtained with application of the lowest amount of water ( $30 \%$ depletion ratio) and sprayed the plants with $1000 \mathrm{mg} \mathrm{l}^{-1}$ of potassium silicate, in both seasons, after one, three and nine MAT. The obtained results may be attributed to the lower evapotranspiration caused as a result of spray sweet pepper plants with the highest concentration (1000 $\mathrm{mg} \mathrm{l}^{-1}$ ) of potassium silicate which increased the thickness of the leaves and protected plants from water loss.

Interaction Effects Between Pruning systems and potassium silicate concentrations

The comparisons among the means of the various treatment combinations, presented in Table (5), illustrated the presence of the interaction effects between the pruning systems and potassium silicate concentrations on the dry mas of varied organs of pepper plant through various growth stages, in both seasons.

The results showed that the highest values of the dry mass of branches, leaves and whole plant of sweet pepper plants after one MAT, were produced from treatment combinations involving pruned plants up to 3 branches and sprayed the plants with $1000 \mathrm{mg} \mathrm{l}^{-1}$ of potassium silicate, in both seasons. However, the highest values of the dry mass of roots at the same growth stage, was obtained from treatment combinations including pruned plants up to 2 branches and sprayed the plants with $1000 \mathrm{mg}$ $1^{-1}$, in both seasons.

In The other growth stages; after three and nine months from transplanting, the results indicated that the highest values of the dry mass of roots, branches and whole plant of sweet pepper plants were achieved from treatment combinations containing un-pruned plants and sprayed the plants with $1000 \mathrm{mg} \mathrm{l}^{-1}$ of potassium silicate, in both seasons. Moreover, the highest values of dry mass of leaves and fruits obtained from treatment combinations including pruned plants up to 3 branches and sprayed the plants with $1000 \mathrm{mg} \mathrm{l}^{-1}$. These significant increases might be due to the positive synergistic effect between the pruning systems and potassium silicate concentrations on the plant metabolism, improving erecting of leaves, increasing solar radiation interception and photosynthetic efficiency, which reflected on the increase dry mass of sweet pepper plant organs through various growth stages.

It is concluded that application of the lowest amount of water (30\% depletion ratio) with pruned pepper plants up to 3 branches plant ${ }^{-1}$ as well as spray the plants with $1000 \mathrm{mg}^{-1}$ of potassium silicate has led to increase the dry mass of the varied organs of sweet pepper plants through various growth stages. Therefore, the combination of water regime, pruning system and foliar application of potassium silicate have the potential to be used to increase the dry mass productivity of sweet pepper grown in calcareous soil under greenhouse, as a low input, safe, environmentally friendly agricultural practices and to save the irrigation water. 
Table 3: First order interaction effect between water regime (Depletion ratio) and pruning systems on the dry weight of root, branches, leaves and whole plant and their of sweet pepper, grown in calcareous soil, under greenhouse conditions, after one, three, nine month from transplanting.

\begin{tabular}{|c|c|c|c|c|c|c|c|c|c|c|c|}
\hline \multirow{3}{*}{$\begin{array}{c}\text { Depletion } \\
\text { Ratio }\end{array}$} & \multirow{3}{*}{ Pruning } & \multicolumn{5}{|c|}{ Dry weight (g) } & \multicolumn{5}{|c|}{ Dry weight (g) } \\
\hline & & Roots & $\begin{array}{c}\text { Branche } \\
\text { s }\end{array}$ & Leaves & Fruits & $\begin{array}{l}\text { Whole } \\
\text { Plant }\end{array}$ & Roots & $\begin{array}{l}\text { Branche } \\
\text { s }\end{array}$ & Leaves & Fruits & $\begin{array}{l}\text { Whole } \\
\text { Plant }\end{array}$ \\
\hline & & \multicolumn{4}{|c|}{ 2016-2017 } & \multicolumn{6}{|c|}{ 2017-2018 } \\
\hline & & & & & & One & MAT & & & & \\
\hline \multirow{3}{*}{$30 \%$} & $\mathrm{P}_{0}^{\mathrm{z}}$ & $4.27 \mathrm{a}$ & $15.77 \mathrm{~b}$ & $4.72 b$ & & $24.76 \mathrm{~b}$ & $4.64 \mathrm{a}$ & $16.84 \mathrm{a}$ & $4.99 \mathrm{c}$ & & $26.47 \mathrm{a}$ \\
\hline & $\mathrm{P}_{1}$ & $4.20 \mathrm{a}$ & $13.17 \mathrm{e}$ & $4.73 b$ & & $22.10 \mathrm{e}$ & $4.61 \mathrm{~b}$ & $14.02 \mathrm{c}$ & $5.25 \mathrm{~b}$ & & $23.88 b c$ \\
\hline & $\mathrm{P}_{2}$ & $4.11 \mathrm{~b}$ & $17.87 \mathrm{a}$ & $5.08 \mathrm{a}$ & & $27.06 \mathrm{a}$ & $4.48 \mathrm{c}$ & $16.79 \mathrm{a}$ & $5.60 \mathrm{a}$ & & $26.87 \mathrm{a}$ \\
\hline \multirow{3}{*}{$50 \%$} & $\mathrm{P}_{0}$ & $3.97 \mathrm{~d}$ & $14.91 \mathrm{c}$ & $3.59 \mathrm{de}$ & & $22.47 \mathrm{~d}$ & $4.23 \mathrm{e}$ & $13.85 \mathrm{c}$ & $3.85 \mathrm{f}$ & & $21.93 \mathrm{e}$ \\
\hline & $P_{1}$ & $3.72 \mathrm{e}$ & $14.15 \mathrm{~d}$ & $3.78 \mathrm{c}$ & & $21.65 \mathrm{f}$ & $3.96 \mathrm{~g}$ & $11.48 \mathrm{~d}$ & $3.99 \mathrm{~d}$ & & $19.43 \mathrm{f}$ \\
\hline & $\mathrm{P}_{2}$ & $4.04 \mathrm{bc}$ & $15.15 \mathrm{c}$ & $3.69 \mathrm{~cd}$ & & $22.88 \mathrm{c}$ & $4.28 \mathrm{~d}$ & $15.47 \mathrm{~b}$ & $3.91 \mathrm{e}$ & & $23.66 \mathrm{c}$ \\
\hline \multirow{3}{*}{$70 \%$} & $\mathrm{P}_{0}$ & $4.00 \mathrm{~cd}$ & $15.16 \mathrm{c}$ & $3.08 \mathrm{~g}$ & & $22.24 \mathrm{de}$ & $4.19 \mathrm{f}$ & $16.05 \mathrm{~b}$ & $3.12 \mathrm{~h}$ & & $23.36 \mathrm{bc}$ \\
\hline & $P_{1}$ & $3.54 \mathrm{f}$ & $14.24 \mathrm{~d}$ & $3.32 \mathrm{f}$ & & $21.10 \mathrm{~g}$ & $3.73 \mathrm{~h}$ & $15.80 \mathrm{~b}$ & $3.16 \mathrm{~h}$ & & $22.69 d$ \\
\hline & $\mathrm{P}_{2}$ & $4.01 \mathrm{c}$ & $14.97 \mathrm{c}$ & $3.55 \mathrm{e}$ & & $22.53 \mathrm{~d}$ & $4.20 \mathrm{f}$ & $15.45 \mathrm{~b}$ & $3.44 \mathrm{~g}$ & & $23.09 \mathrm{~b}$ \\
\hline & & \multicolumn{10}{|c|}{ Three MAT } \\
\hline \multirow{3}{*}{$30 \%$} & $\mathrm{P}_{0}$ & $15.02 \mathrm{a}^{\mathrm{y}}$ & $94.05 \mathrm{a}$ & $8.57 \mathrm{c}$ & $23.42 \mathrm{~b}$ & $141.06 \mathrm{a}$ & $15.89 \mathrm{a}$ & $86.72 \mathrm{a}$ & $8.96 \mathrm{c}$ & $27.30 \mathrm{~b}$ & $138.87 \mathrm{a}$ \\
\hline & $\mathrm{P}_{1}$ & $7.33 \mathrm{e}$ & $32.14 \mathrm{~g}$ & $8.90 \mathrm{~b}$ & $22.46 \mathrm{c}$ & $70.83 \mathrm{e}$ & $7.85 \mathrm{~d}$ & $34.35 \mathrm{e}$ & $9.13 \mathrm{~b}$ & $26.84 \mathrm{c}$ & $78.17 \mathrm{~d}$ \\
\hline & $\mathrm{P}_{2}$ & $12.08 \mathrm{~b}$ & $56.22 \mathrm{c}$ & $11.05 \mathrm{a}$ & $25.46 \mathrm{a}$ & $104.81 \mathrm{~b}$ & $12.79 \mathrm{~b}$ & $48.50 \mathrm{c}$ & $11.47 \mathrm{a}$ & $29.00 \mathrm{a}$ & $101.76 \mathrm{~b}$ \\
\hline \multirow{3}{*}{$50 \%$} & $\mathrm{P}_{0}$ & $7.97 \mathrm{c}$ & $57.49 \mathrm{~b}$ & $4.22 \mathrm{~g}$ & $14.51 \mathrm{f}$ & $84.19 \mathrm{c}$ & $8.19 \mathrm{c}$ & $61.60 \mathrm{~b}$ & $4.47 \mathrm{~h}$ & $15.22 \mathrm{~h}$ & $89.48 \mathrm{c}$ \\
\hline & $P_{1}$ & $5.12 \mathrm{~h}$ & $25.37 \mathrm{i}$ & $6.14 \mathrm{~d}$ & $16.33 \mathrm{~d}$ & $52.96 \mathrm{~h}$ & $5.30 \mathrm{~g}$ & $27.60 \mathrm{~g}$ & $6.46 \mathrm{~d}$ & $17.99 \mathrm{e}$ & $57.35 \mathrm{~h}$ \\
\hline & $\mathrm{P}_{2}$ & $5.78 \mathrm{f}$ & $35.62 \mathrm{e}$ & $5.30 \mathrm{f}$ & $14.13 \mathrm{~g}$ & $60.83 \mathrm{f}$ & $5.98 \mathrm{e}$ & $38.96 \mathrm{~d}$ & $5.53 \mathrm{~g}$ & $18.68 \mathrm{~d}$ & $69.15 \mathrm{f}$ \\
\hline \multirow{3}{*}{$70 \%$} & $\mathrm{P}_{0}$ & $7.50 \mathrm{~d}$ & $48.95 \mathrm{~d}$ & $4.20 \mathrm{~g}$ & $12.03 \mathrm{~h}$ & $72.68 \mathrm{~d}$ & $7.87 \mathrm{~d}$ & $47.73 \mathrm{c}$ & $4.47 \mathrm{~h}$ & $14.89 \mathrm{i}$ & $74.96 \mathrm{e}$ \\
\hline & $\mathrm{P}_{1}$ & $4.93 \mathrm{i}$ & $26.83 \mathrm{~h}$ & $5.55 \mathrm{e}$ & $15.94 \mathrm{e}$ & $53.25 \mathrm{~h}$ & $5.15 \mathrm{~g}$ & $20.50 \mathrm{~h}$ & $5.89 \mathrm{e}$ & $16.70 \mathrm{f}$ & $48.24 \mathrm{i}$ \\
\hline & $\mathrm{P}_{2}$ & $5.24 \mathrm{~g}$ & $33.15 \mathrm{f}$ & $5.44 \mathrm{e}$ & $13.89 \mathrm{~g}$ & $57.72 \mathrm{~g}$ & $5.49 \mathrm{f}$ & $32.74 \mathrm{f}$ & $5.72 \mathrm{f}$ & $15.60 \mathrm{~g}$ & $59.55 \mathrm{~g}$ \\
\hline & & \multicolumn{10}{|c|}{ Nine MAT } \\
\hline \multirow{3}{*}{$30 \%$} & $\mathrm{P}_{0}$ & $19.74 \mathrm{a}^{\mathrm{y}}$ & $169.00 \mathrm{a}$ & $10.33 \mathrm{~b}$ & $516.62 \mathrm{~b}$ & $715.69 \mathrm{a}$ & $20.91 \mathrm{a}$ & $159.31 \mathrm{a}$ & $10.96 \mathrm{~b}$ & $520.89 \mathrm{~b}$ & $712.07 \mathrm{a}$ \\
\hline & $P_{1}$ & $8.71 \mathrm{e}$ & $65.85 \mathrm{e}$ & $10.21 \mathrm{c}$ & $503.51 \mathrm{c}$ & $588.28 \mathrm{c}$ & $9.23 \mathrm{e}$ & $70.30 \mathrm{e}$ & $10.84 \mathrm{c}$ & $516.36 \mathrm{c}$ & $606.73 \mathrm{c}$ \\
\hline & $\mathrm{P}_{2}$ & $15.69 \mathrm{~b}$ & $82.28 \mathrm{~d}$ & $12.49 \mathrm{a}$ & $521.81 \mathrm{a}$ & $632.27 \mathrm{~b}$ & $16.51 \mathrm{~b}$ & $75.34 \mathrm{~d}$ & $13.17 \mathrm{a}$ & $532.91 \mathrm{a}$ & $637.93 \mathrm{~b}$ \\
\hline \multirow{3}{*}{$50 \%$} & $\mathrm{P}_{0}$ & $9.85 \mathrm{~d}$ & $91.00 \mathrm{c}$ & $5.81 \mathrm{~h}$ & $231.81 \mathrm{~d}$ & $338.47 \mathrm{f}$ & $10.20 \mathrm{~d}$ & $92.29 \mathrm{c}$ & $6.19 \mathrm{~h}$ & $228.35 \mathrm{e}$ & $337.03 \mathrm{~g}$ \\
\hline & $\mathrm{P}_{1}$ & $6.02 \mathrm{~g}$ & $46.82 \mathrm{i}$ & $6.92 \mathrm{e}$ & $174.46 \mathrm{i}$ & $234.22 \mathrm{~h}$ & $6 . .39 \mathrm{~g}$ & $41.34 \mathrm{i}$ & $7.41 \mathrm{e}$ & $171.85 \mathrm{i}$ & $226.99 \mathrm{~h}$ \\
\hline & $\mathrm{P}_{2}$ & $7.28 \mathrm{f}$ & $51.35 \mathrm{~h}$ & $6.78 \mathrm{f}$ & $199.29 \mathrm{~h}$ & $264.70 \mathrm{~g}$ & $7.63 \mathrm{f}$ & $52.75 \mathrm{~h}$ & $7.17 \mathrm{f}$ & $198.23 \mathrm{~h}$ & $265.78 \mathrm{~g}$ \\
\hline \multirow{3}{*}{$70 \%$} & $\mathrm{P}_{0}$ & $10.76 \mathrm{c}$ & $104.67 \mathrm{~b}$ & $5.29 \mathrm{i}$ & $228.82 \mathrm{e}$ & $349.54 \mathrm{e}$ & $11.19 \mathrm{c}$ & $100.72 b$ & $5.52 \mathrm{i}$ & $229.11 \mathrm{~d}$ & $346.54 \mathrm{e}$ \\
\hline & $P_{1}$ & $5.85 \mathrm{~g}$ & $55.50 \mathrm{~g}$ & $7.27 \mathrm{~d}$ & $210.05 \mathrm{~g}$ & $278.67 \mathrm{~d}$ & $6.08 \mathrm{~h}$ & $55.41 \mathrm{~g}$ & $7.55 \mathrm{~d}$ & $210.50 \mathrm{~g}$ & $279.54 d$ \\
\hline & $\mathrm{P}_{2}$ & $7.40 \mathrm{f}$ & $59.64 \mathrm{f}$ & $6.26 \mathrm{~g}$ & $225.62 \mathrm{f}$ & $298.92 \mathrm{f}$ & $7.59 \mathrm{f}$ & $62.54 \mathrm{f}$ & $6.44 \mathrm{~g}$ & $226.45 \mathrm{f}$ & $303.02 \mathrm{f}$ \\
\hline
\end{tabular}

Y. Values marked with the same letter (s) are statistically similar using Revised LSD test at $\mathrm{p}=0.05$. Uppercase letter (s) indicate differences between main effects, and lower case letter(s) indicate differences within interaction of each character.

${ }^{\mathbf{Z}}$ Pruning treatments: $\mathbf{P}_{\mathbf{0}}=$ without pruning (Spanish system) and $\mathbf{P}_{\mathbf{1}}=$ two stems and $\mathbf{P}_{\mathbf{2}}=$ three stems plant ${ }^{-1}$ (Holland system). 
Table 4: First order interaction effects between water regime (Depletion ratio) and potassium silicate on the dry weight of root, branches, leaves and whole plant and their of sweet pepper, grown in calcareous soil, under greenhouse conditions, after one, three, nine month from transplanting.

\begin{tabular}{|c|c|c|c|c|c|c|c|c|c|c|c|}
\hline \multirow{3}{*}{$\begin{array}{c}\text { Depletion } \\
\text { Ratio }\end{array}$} & \multirow{3}{*}{$\begin{array}{c}\text { Potassium } \\
\text { silicate } \\
\mathrm{mg} \mathrm{l}^{-1}\end{array}$} & \multicolumn{5}{|c|}{ Dry weight (g) } & \multicolumn{5}{|c|}{ Dry weight (g) } \\
\hline & & Roots & Branches & Leaves & Fruits & $\begin{array}{l}\text { Whole } \\
\text { Plant }\end{array}$ & Roots & Branches & Leaves & Fruits & $\begin{array}{l}\text { Whole } \\
\text { Plant }\end{array}$ \\
\hline & & \multicolumn{5}{|c|}{ 2016-2017 } & \multicolumn{5}{|c|}{ 2017-2018 } \\
\hline & & \multicolumn{10}{|c|}{ One MAT } \\
\hline \multirow{4}{*}{$30 \%$} & $\mathbf{0}$ & $3.88 \mathrm{~d}$ & $14.24 \mathrm{~g}$ & $4.09 \mathrm{~d}$ & & $22.21 \mathrm{f}$ & $4.26 \mathrm{f}$ & $12.81 \mathrm{~g}$ & $4.62 \mathrm{~d}$ & & $21.69 \mathrm{~g}$ \\
\hline & 250 & $3.93 \mathrm{~d}$ & $14.88 \mathrm{f}$ & $4.39 \mathrm{c}$ & & $23.20 \mathrm{e}$ & $4.32 \mathrm{e}$ & $13.51 \mathrm{f}$ & $4.71 \mathrm{c}$ & & $22.54 \mathrm{e}$ \\
\hline & 500 & $4.32 \mathrm{~b}$ & $15.94 \mathrm{~d}$ & $5.27 \mathrm{~b}$ & & $25.53 \mathrm{~b}$ & $4.69 \mathrm{c}$ & $17.16 \mathrm{c}$ & $5.70 \mathrm{~b}$ & & $27.55 \mathrm{~b}$ \\
\hline & 1000 & $4.64 \mathrm{a}$ & $17.36 \mathrm{a}$ & $5.62 \mathrm{a}$ & & $27.62 \mathrm{a}$ & $5.04 \mathrm{a}$ & $18.15 \mathrm{a}$ & $6.10 \mathrm{a}$ & & $29.29 \mathrm{a}$ \\
\hline \multirow{4}{*}{$50 \%$} & $\mathbf{0}$ & $3.56 \mathrm{f}$ & $13.40 \mathrm{~h}$ & $3.00 \mathrm{j}$ & & $19.96 \mathrm{j}$ & $3.74 \mathrm{i}$ & $15.32 \mathrm{~d}$ & $2.99 \mathrm{k}$ & & $22.05 \mathrm{fg}$ \\
\hline & 250 & $3.71 \mathrm{e}$ & $13.46 \mathrm{~h}$ & $3.41 \mathrm{~h}$ & & $20.58 \mathrm{~h}$ & $3.92 \mathrm{~g}$ & $14.79 \mathrm{e}$ & $3.31 \mathrm{j}$ & & $22.02 \mathrm{fg}$ \\
\hline & 500 & $3.55 \mathrm{f}$ & $15.45 \mathrm{e}$ & $3.24 \mathrm{i}$ & & $22.24 \mathrm{f}$ & $3.72 \mathrm{i}$ & $17.64 \mathrm{~b}$ & $3.28 \mathrm{j}$ & & $20.92 \mathrm{~d}$ \\
\hline & 1000 & $4.60 \mathrm{a}$ & $16.85 \mathrm{~b}$ & $3.62 \mathrm{~g}$ & & $25.07 \mathrm{c}$ & $4.79 \mathrm{~b}$ & $17.21 \mathrm{c}$ & $3.38 \mathrm{i}$ & & $25.38 \mathrm{c}$ \\
\hline \multirow{5}{*}{$70 \%$} & $\mathbf{0}$ & $3.61 \mathrm{f}$ & $13.19 \mathrm{i}$ & $3.37 \mathrm{~h}$ & & $20.17 \mathrm{i}$ & $3.88 \mathrm{~h}$ & $13.48 \mathrm{f}$ & $3.76 \mathrm{~h}$ & & $21.12 \mathrm{~h}$ \\
\hline & 250 & $3.69 \mathrm{e}$ & $13.59 \mathrm{~h}$ & $3.72 \mathrm{f}$ & & $21.00 \mathrm{~g}$ & $3.90 \mathrm{~g}$ & $12.83 \mathrm{~g}$ & $3.81 \mathrm{~g}$ & & $20.54 \mathrm{i}$ \\
\hline & 500 & $4.01 \mathrm{c}$ & $15.59 \mathrm{e}$ & $3.68 \mathrm{fg}$ & & $23.28 \mathrm{e}$ & $4.27 \mathrm{f}$ & $14.64 \mathrm{e}$ & $4.00 \mathrm{f}$ & & $22.91 \mathrm{e}$ \\
\hline & 1000 & $4.35 \mathrm{~b}$ & $16.57 \mathrm{c}$ & $3.96 \mathrm{e}$ & & $24.88 \mathrm{~d}$ & $4.58 \mathrm{~d}$ & $13.45 \mathrm{f}$ & $4.09 \mathrm{e}$ & & $22.12 \mathrm{f}$ \\
\hline & & \multicolumn{10}{|c|}{ Three MAT } \\
\hline \multirow{4}{*}{$30 \%$} & $\mathbf{0}$ & $10.50 \mathrm{~d}^{\mathrm{y}}$ & $55.81 \mathrm{~d}$ & $8.57 \mathrm{~d}$ & $21.12 \mathrm{c}$ & $96.00 \mathrm{~d}$ & $11.31 \mathrm{~d}$ & $48.91 \mathrm{~d}$ & $8.94 \mathrm{~d}$ & $24.01 \mathrm{~d}$ & $93.17 \mathrm{~d}$ \\
\hline & 250 & $11.16 \mathrm{c}$ & $57.35 \mathrm{c}$ & $8.94 \mathrm{c}$ & $21.38 \mathrm{c}$ & $98.83 \mathrm{c}$ & $11.86 \mathrm{c}$ & $49.76 \mathrm{c}$ & $9.09 \mathrm{c}$ & $24.95 \mathrm{c}$ & $95.66 \mathrm{c}$ \\
\hline & 500 & $11.77 \mathrm{~b}$ & $64.57 \mathrm{~b}$ & $10.18 \mathrm{~b}$ & $25.76 \mathrm{~b}$ & $112.28 \mathrm{~b}$ & $12.38 \mathrm{~b}$ & $62.24 \mathrm{~b}$ & $10.61 \mathrm{~b}$ & $30.46 \mathrm{~b}$ & $115.69 \mathrm{~b}$ \\
\hline & 1000 & $12.46 \mathrm{a}$ & $65.49 \mathrm{a}$ & $10.35 \mathrm{a}$ & $26.86 \mathrm{a}$ & $115.16 \mathrm{a}$ & $13.16 \mathrm{a}$ & $65.18 \mathrm{a}$ & $10.77 \mathrm{a}$ & $31.42 \mathrm{a}$ & $120.53 \mathrm{a}$ \\
\hline \multirow{4}{*}{$50 \%$} & $\mathbf{0}$ & $5.78 \mathrm{i}$ & $37.16 \mathrm{~h}$ & $5.17 \mathrm{~g}$ & $14.70 \mathrm{e}$ & $62.81 \mathrm{~h}$ & $5.94 \mathrm{i}$ & $40.40 \mathrm{~g}$ & $5.48 \mathrm{~g}$ & $15.65 \mathrm{~h}$ & $67.47 \mathrm{~h}$ \\
\hline & 250 & $5.87 \mathrm{~h}$ & $37.03 \mathrm{~h}$ & $5.14 \mathrm{~g}$ & $14.51 \mathrm{e}$ & $62.55 \mathrm{~h}$ & $6.09 \mathrm{~h}$ & $40.11 \mathrm{~g}$ & $5.41 \mathrm{~h}$ & $16.61 \mathrm{~g}$ & $68.22 \mathrm{~g}$ \\
\hline & 500 & $5.76 \mathrm{i}$ & $42.26 \mathrm{e}$ & $5.23 \mathrm{fg}$ & $12.94 \mathrm{~g}$ & $66.19 \mathrm{f}$ & $5.94 \mathrm{i}$ & $45.54 \mathrm{~d}$ & $5.47 \mathrm{~g}$ & $17.79 \mathrm{f}$ & $74.74 \mathrm{f}$ \\
\hline & 1000 & $7.75 \mathrm{e}$ & $41.51 \mathrm{f}$ & $5.34 \mathrm{ef}$ & $17.80 \mathrm{~d}$ & $72.40 \mathrm{e}$ & $7.98 \mathrm{e}$ & $44.83 \mathrm{f}$ & $5.59 \mathrm{f}$ & $19.14 \mathrm{e}$ & $77.54 \mathrm{e}$ \\
\hline \multirow{5}{*}{$70 \%$} & $\mathbf{0}$ & $5.38 \mathrm{k}$ & $34.90 \mathrm{k}$ & $4.74 \mathrm{i}$ & $13.20 \mathrm{~g}$ & $58.22 \mathrm{k}$ & $5.68 \mathrm{j}$ & $34.06 \mathrm{~h}$ & $5.01 \mathrm{j}$ & $13.89 \mathrm{j}$ & $58.64 \mathrm{k}$ \\
\hline & 250 & $5.65 \mathrm{j}$ & $36.49 \mathrm{i}$ & $5.18 \mathrm{~g}$ & $14.51 \mathrm{e}$ & $61.83 \mathrm{i}$ & $5.90 \mathrm{i}$ & $33.68 \mathrm{i}$ & $5.51 \mathrm{~g}$ & $14.80 \mathrm{i}$ & $59.89 \mathrm{j}$ \\
\hline & 500 & $6.10 \mathrm{~g}$ & $35.69 \mathrm{j}$ & $4.88 \mathrm{~h}$ & $13.71 \mathrm{f}$ & $60.38 \mathrm{j}$ & $6.41 \mathrm{~g}$ & $34.30 \mathrm{~h}$ & $5.16 \mathrm{i}$ & $16.65 \mathrm{~g}$ & $62.52 \mathrm{i}$ \\
\hline & 1000 & $6.43 \mathrm{f}$ & $38.18 \mathrm{~g}$ & $5.45 \mathrm{e}$ & $14.39 \mathrm{e}$ & $64.45 \mathrm{~g}$ & $6.69 \mathrm{f}$ & $32.60 \mathrm{j}$ & $5.75 \mathrm{e}$ & $17.57 \mathrm{f}$ & $62.61 \mathrm{i}$ \\
\hline & & \multicolumn{10}{|c|}{ Nine MAT } \\
\hline \multirow{4}{*}{$30 \%$} & $\mathbf{0}$ & $13.84 \mathrm{~d}^{\mathrm{y}}$ & $96.16 \mathrm{c}$ & $10.19 \mathrm{c}$ & $413.32 \mathrm{~d}$ & $533.51 \mathrm{~d}$ & $14.61 \mathrm{~d}$ & $91.07 \mathrm{c}$ & $10.86 \mathrm{~d}$ & $419.76 \mathrm{~d}$ & $536.30 \mathrm{~d}$ \\
\hline & 250 & $14.27 \mathrm{c}$ & $100.66 \mathrm{~b}$ & $10.23 \mathrm{c}$ & $467.87 \mathrm{c}$ & $593.03 \mathrm{c}$ & $15.19 \mathrm{c}$ & $93.90 \mathrm{~b}$ & $10.93 \mathrm{c}$ & $483.62 \mathrm{c}$ & $603.64 \mathrm{c}$ \\
\hline & 500 & $14.69 \mathrm{~b}$ & $112.94 \mathrm{a}$ & $11.53 \mathrm{~b}$ & $560.22 \mathrm{~b}$ & $699.38 \mathrm{~b}$ & $15.50 \mathrm{~b}$ & $110.59 \mathrm{a}$ & $12.13 b$ & $566.65 \mathrm{~b}$ & $704.87 \mathrm{~b}$ \\
\hline & 1000 & $16.06 \mathrm{a}$ & $113.08 \mathrm{a}$ & $12.08 \mathrm{a}$ & $614.51 \mathrm{a}$ & $755.73 \mathrm{a}$ & $16.88 \mathrm{a}$ & $111.04 \mathrm{a}$ & $12.71 \mathrm{a}$ & $623.51 \mathrm{a}$ & $764.14 \mathrm{a}$ \\
\hline \multirow{4}{*}{$50 \%$} & $\mathbf{0}$ & $6.64 \mathrm{i}$ & $61.47 \mathrm{j}$ & $5.93 \mathrm{~h}$ & $175.88 \mathrm{j}$ & $249.92 \mathrm{k}$ & $6.86 \mathrm{j}$ & $61.22 \mathrm{i}$ & $6.35 \mathrm{j}$ & 173.171 & 247.601 \\
\hline & 250 & $7.13 \mathrm{~h}$ & $58.03 \mathrm{k}$ & $6.17 \mathrm{~g}$ & $229.90 \mathrm{f}$ & $301.23 \mathrm{~g}$ & $7.47 \mathrm{i}$ & $60.87 \mathrm{i}$ & $6.53 \mathrm{~h}$ & $227.35 \mathrm{~g}$ & $302.22 \mathrm{~h}$ \\
\hline & 500 & $8.08 \mathrm{f}$ & $65.90 \mathrm{i}$ & $6.68 \mathrm{e}$ & $224.50 \mathrm{~g}$ & $305.16 \mathrm{~h}$ & $8.51 \mathrm{f}$ & $62.55 \mathrm{~h}$ & $7.10 \mathrm{f}$ & $221.63 \mathrm{~h}$ & $299.79 \mathrm{i}$ \\
\hline & 1000 & $9.03 \mathrm{e}$ & $66.83 \mathrm{~h}$ & $7.23 \mathrm{~d}$ & $177.13 \mathrm{j}$ & $260.22 \mathrm{j}$ & $9.45 \mathrm{e}$ & $63.86 \mathrm{~g}$ & $7.73 \mathrm{e}$ & $175.76 \mathrm{k}$ & $256.80 \mathrm{k}$ \\
\hline \multirow{4}{*}{$70 \%$} & $\mathbf{0}$ & $7.47 \mathrm{~g}$ & $70.50 \mathrm{f}$ & $6.16 \mathrm{~g}$ & $196.09 \mathrm{i}$ & $280.22 \mathrm{i}$ & $7.67 \mathrm{~h}$ & $61.20 \mathrm{i}$ & $6.38 \mathrm{ij}$ & $197.38 \mathrm{j}$ & $272.63 \mathrm{j}$ \\
\hline & 250 & $7.49 \mathrm{~g}$ & $69.37 \mathrm{~g}$ & $6.15 \mathrm{~g}$ & $236.83 \mathrm{e}$ & $319.84 \mathrm{f}$ & $7.73 \mathrm{~h}$ & $72.01 \mathrm{f}$ & $6.41 \mathrm{i}$ & $233.85 \mathrm{f}$ & $320.00 \mathrm{~g}$ \\
\hline & 500 & $8.03 \mathrm{f}$ & $74.04 \mathrm{e}$ & $6.18 \mathrm{~g}$ & $215.43 \mathrm{~h}$ & $303.68 \mathrm{~g}$ & $8.30 \mathrm{~g}$ & $76.06 \mathrm{e}$ & $6.33 \mathrm{j}$ & $216.02 \mathrm{i}$ & $306.71 \mathrm{f}$ \\
\hline & 1000 & $9.02 \mathrm{e}$ & $79.17 \mathrm{~d}$ & $6.59 \mathrm{f}$ & $237.65 \mathrm{e}$ & $332.43 \mathrm{e}$ & $9.45 \mathrm{e}$ & $82.28 \mathrm{~d}$ & $6.90 \mathrm{~g}$ & $240.82 \mathrm{e}$ & $339.45 \mathrm{e}$ \\
\hline
\end{tabular}

y. Values marked with the same letter (s) are statistically similar using Revised LSD test at $\mathrm{p}=0.05$. Uppercase letter (s) indicate differences between main effects, and lower case letter(s) indicate differences within interaction of each character. 
Table 5:First order interaction effect between pruning systems and potassium silicate on the dry weight of root, branches, leaves and whole plant and their of sweet pepper, grown in calcareous soil, under greenhouse conditions, after one, three, nine months from transplanting.

\begin{tabular}{|c|c|c|c|c|c|c|c|c|c|c|c|}
\hline \multirow{3}{*}{ Pruning } & \multirow{3}{*}{$\begin{array}{c}\text { Potassium } \\
\text { silicate } \\
\mathrm{mg} \mathrm{l}^{-1}\end{array}$} & \multicolumn{5}{|c|}{ Dry weight (g) } & \multicolumn{5}{|c|}{ Dry weight (g) } \\
\hline & & Roots & Branches & Leaves & Fruits & $\begin{array}{l}\text { Whole } \\
\text { Plant }\end{array}$ & Roots & Branches & Leaves & Fruits & $\begin{array}{l}\text { Whole } \\
\text { Plant }\end{array}$ \\
\hline & & \multicolumn{5}{|c|}{ 2016-2017 } & \multicolumn{5}{|c|}{$2017-2018$} \\
\hline & & & & & & One & & & & & \\
\hline \multirow{4}{*}{$\mathrm{P}_{0}^{\mathrm{z}}$} & 0 & $3.82 \mathrm{f}$ & $13.63 \mathrm{f}$ & $3.50 \mathrm{~g}$ & & $20.95 \mathrm{i}$ & $4.09 \mathrm{~g}$ & $14.10 \mathrm{~g}$ & $3.71 \mathrm{~h}$ & & $21.90 \mathrm{ef}$ \\
\hline & 250 & $3.88 \mathrm{e}$ & $13.92 \mathrm{e}$ & $3.67 \mathrm{f}$ & & $21.47 \mathrm{~h}$ & $4.15 \mathrm{f}$ & $14.57 \mathrm{e}$ & $3.82 \mathrm{~g}$ & & $22.54 \mathrm{~d}$ \\
\hline & 500 & $4.21 \mathrm{~d}$ & $16.37 \mathrm{~b}$ & $3.94 \mathrm{e}$ & & $24.52 \mathrm{e}$ & $4.47 \mathrm{e}$ & $17.02 \mathrm{c}$ & $4.17 \mathrm{e}$ & & $25.66 \mathrm{~b}$ \\
\hline & 1000 & $4.42 \mathrm{c}$ & $17.20 \mathrm{a}$ & $4.07 \mathrm{~d}$ & & $25.69 \mathrm{~b}$ & $4.71 \mathrm{c}$ & $16.62 \mathrm{~d}$ & $4.25 \mathrm{~d}$ & & $25.58 \mathrm{~b}$ \\
\hline \multirow{4}{*}{$\mathrm{P}_{1}$} & 0 & $3.63 \mathrm{~g}$ & $12.43 \mathrm{~g}$ & $3.50 \mathrm{~g}$ & & $19.56 \mathrm{k}$ & $3.90 \mathrm{~h}$ & $13.34 \mathrm{hi}$ & $3.84 \mathrm{fg}$ & & $21.08 \mathrm{~g}$ \\
\hline & 250 & $3.63 \mathrm{~g}$ & $12.58 \mathrm{~g}$ & $3.73 \mathrm{f}$ & & $19.94 \mathrm{j}$ & $3.90 \mathrm{hi}$ & $13.03 \mathrm{i}$ & $3.86 \mathrm{f}$ & & $20.79 \mathrm{~g}$ \\
\hline & 500 & $3.41 \mathrm{~h}$ & $14.06 \mathrm{e}$ & $4.08 \mathrm{~d}$ & & $21.55 \mathrm{~h}$ & $3.70 \mathrm{j}$ & $14.21 \mathrm{efg}$ & $4.28 \mathrm{c}$ & & $22.19 \mathrm{de}$ \\
\hline & 1000 & $4.62 \mathrm{a}$ & $16.34 \mathrm{~b}$ & $4.47 \mathrm{~b}$ & & $25.43 \mathrm{c}$ & $4.90 \mathrm{a}$ & 14.49 ef & $4.56 \mathrm{~b}$ & & $23.95 \mathrm{c}$ \\
\hline \multirow{4}{*}{$\mathrm{P}_{2}$} & 0 & $3.61 \mathrm{~g}$ & $14.76 \mathrm{~d}$ & $3.46 \mathrm{~g}$ & & $21.83 \mathrm{~g}$ & $3.88 \mathrm{i}$ & $14.17 \mathrm{fg}$ & $3.82 \mathrm{~g}$ & & $21.87 \mathrm{ef}$ \\
\hline & 250 & $3.82 \mathrm{f}$ & $15.43 \mathrm{c}$ & $4.12 \mathrm{~cd}$ & & $23.37 \mathrm{f}$ & $4.09 \mathrm{~g}$ & $13.53 \mathrm{~h}$ & $4.15 \mathrm{e}$ & & $21.77 \mathrm{f}$ \\
\hline & 500 & $4.26 \mathrm{~d}$ & $16.55 \mathrm{~b}$ & $4.18 \mathrm{c}$ & & $24.99 \mathrm{~d}$ & $4.51 \mathrm{~d}$ & $18.22 \mathrm{a}$ & $4.54 \mathrm{~b}$ & & $27.27 \mathrm{a}$ \\
\hline & 1000 & $4.5 \mathrm{~b}$ & $17.24 \mathrm{a}$ & $4.66 \mathrm{a}$ & & $26.45 \mathrm{a}$ & $4.79 \mathrm{~b}$ & $17.68 \mathrm{~b}$ & $4.77 \mathrm{a}$ & & $27.24 a$ \\
\hline & & \multicolumn{10}{|c|}{ Three MAT } \\
\hline \multirow{4}{*}{$\mathrm{P}_{0}$} & 0 & $9.56 \mathrm{c}^{\mathrm{y}}$ & $64.03 \mathrm{~d}$ & $5.36 \mathrm{i}$ & $16.09 \mathrm{f}$ & $95.04 \mathrm{~d}$ & $10.06 \mathrm{c}$ & $62.39 \mathrm{~b}$ & $5.68 \mathrm{k}$ & $16.97 \mathrm{k}$ & $95.10 \mathrm{c}$ \\
\hline & 250 & $9.60 \mathrm{c}$ & $65.46 \mathrm{c}$ & $5.49 \mathrm{~h}$ & $16.07 \mathrm{f}$ & $96.62 \mathrm{c}$ & $10.06 \mathrm{c}$ & $61.94 \mathrm{c}$ & $5.79 \mathrm{j}$ & $17.56 \mathrm{j}$ & $95.35 \mathrm{c}$ \\
\hline & 500 & $10.34 \mathrm{~b}$ & $68.36 \mathrm{~b}$ & $5.74 \mathrm{~g}$ & $16.79 \mathrm{e}$ & $101.23 \mathrm{~b}$ & $10.78 \mathrm{~b}$ & $68.62 \mathrm{a}$ & $6.06 \mathrm{i}$ & $20.55 \mathrm{f}$ & $106.01 \mathrm{~b}$ \\
\hline & 1000 & $11.16 \mathrm{a}$ & $69.47 \mathrm{a}$ & $6.07 \mathrm{f}$ & $17.66 \mathrm{~d}$ & $104.36 \mathrm{a}$ & $11.71 \mathrm{a}$ & $68.44 \mathrm{a}$ & $6.34 \mathrm{~h}$ & $21.46 \mathrm{e}$ & $107.95 \mathrm{a}$ \\
\hline \multirow{4}{*}{$\mathrm{P}_{1}$} & 0 & $5.03 \mathrm{j}$ & $25.49 \mathrm{k}$ & $6.62 \mathrm{e}$ & $16.20 \mathrm{f}$ & 53.341 & $5.45 \mathrm{j}$ & $25.28 \mathrm{k}$ & $6.94 \mathrm{f}$ & $18.22 \mathrm{i}$ & $55.89 \mathrm{k}$ \\
\hline & 250 & $5.60 \mathrm{i}$ & $26.91 \mathrm{j}$ & $6.79 \mathrm{~d}$ & $18.10 \mathrm{c}$ & $57.40 \mathrm{k}$ & $5.90 \mathrm{i}$ & $26.29 \mathrm{j}$ & $6.95 \mathrm{f}$ & $19.19 \mathrm{~h}$ & $58.33 \mathrm{j}$ \\
\hline & 500 & $5.61 \mathrm{i}$ & $29.84 \mathrm{i}$ & $6.81 \mathrm{~d}$ & $17.17 \mathrm{e}$ & $59.43 \mathrm{j}$ & $5.86 \mathrm{i}$ & $29.42 \mathrm{~h}$ & $7.15 \mathrm{e}$ & $21.69 \mathrm{~d}$ & $64.12 \mathrm{i}$ \\
\hline & 1000 & $6.94 \mathrm{~h}$ & $30.22 \mathrm{~h}$ & $7.24 \mathrm{~b}$ & $21.50 \mathrm{a}$ & $65.90 \mathrm{i}$ & $7.19 \mathrm{~h}$ & $28.94 \mathrm{i}$ & $7.60 \mathrm{c}$ & $22.94 \mathrm{~b}$ & $66.67 \mathrm{~h}$ \\
\hline \multirow{4}{*}{$\mathrm{P}_{2}$} & 0 & $7.06 \mathrm{~g}$ & $38.34 \mathrm{~g}$ & $6.50 \mathrm{e}$ & $16.74 \mathrm{e}$ & $68.64 \mathrm{~h}$ & $7.42 \mathrm{~g}$ & $35.70 \mathrm{f}$ & $6.81 \mathrm{~g}$ & $18.37 \mathrm{i}$ & $68.30 \mathrm{~g}$ \\
\hline & 250 & $7.50 \mathrm{f}$ & $38.50 \mathrm{~g}$ & $6.99 \mathrm{c}$ & $16.23 \mathrm{f}$ & $69.22 \mathrm{~g}$ & $7.90 \mathrm{f}$ & $35.31 \mathrm{~g}$ & $7.27 \mathrm{~d}$ & $19.62 \mathrm{~g}$ & $70.10 \mathrm{f}$ \\
\hline & 500 & $7.68 \mathrm{e}$ & $44.32 \mathrm{f}$ & $7.74 \mathrm{a}$ & $18.44 \mathrm{c}$ & $78.18 \mathrm{f}$ & $8.09 \mathrm{e}$ & $44.04 \mathrm{e}$ & $8.03 \mathrm{~b}$ & $22.66 \mathrm{c}$ & $82.82 \mathrm{e}$ \\
\hline & 1000 & $8.55 \mathrm{~d}$ & $45.49 \mathrm{e}$ & $7.83 \mathrm{a}$ & $19.89 \mathrm{~b}$ & $81.76 \mathrm{e}$ & $8.93 \mathrm{~d}$ & $45.22 \mathrm{~d}$ & $8.17 \mathrm{a}$ & $23.73 \mathrm{a}$ & $86.05 \mathrm{~d}$ \\
\hline & & \multicolumn{10}{|c|}{ Nine MAT } \\
\hline \multirow{4}{*}{$\mathrm{P}_{0}$} & 0 & $12.63 \mathrm{c}^{\mathrm{y}}$ & $114.20 \mathrm{~b}$ & $6.77 \mathrm{j}$ & $288.60 \mathrm{~h}$ & $422.20 \mathrm{~h}$ & $13.11 \mathrm{~d}$ & $102.20 \mathrm{~d}$ & $7.20 \mathrm{j}$ & $289.47 \mathrm{i}$ & $411.98 \mathrm{j}$ \\
\hline & 250 & $12.65 \mathrm{c}$ & $113.67 \mathrm{~b}$ & $6.67 \mathrm{k}$ & $296.80 \mathrm{~g}$ & $429.79 \mathrm{~g}$ & $13.30 \mathrm{c}$ & $112.97 \mathrm{c}$ & $7.06 \mathrm{k}$ & $299.77 \mathrm{~h}$ & $433.10 \mathrm{~h}$ \\
\hline & 500 & $13.51 \mathrm{~b}$ & $129.00 \mathrm{a}$ & $7.45 \mathrm{i}$ & $356.03 \mathrm{a}$ & $505.99 \mathrm{a}$ & $14.20 \mathrm{~b}$ & $125.58 \mathrm{~b}$ & $7.89 \mathrm{i}$ & $359.22 \mathrm{a}$ & $506.89 \mathrm{a}$ \\
\hline & 1000 & $14.99 \mathrm{a}$ & $129.36 \mathrm{a}$ & $7.68 \mathrm{~g}$ & $344.10 \mathrm{~b}$ & $496.13 b$ & $15.79 \mathrm{a}$ & $129.00 \mathrm{a}$ & $8.09 \mathrm{~h}$ & $349.97 b$ & $502.85 \mathrm{~b}$ \\
\hline \multirow{4}{*}{$\mathrm{P}_{1}$} & 0 & $6.16 \mathrm{k}$ & $53.06 \mathrm{i}$ & $7.91 \mathrm{e}$ & $239.39 \mathrm{j}$ & $306.52 \mathrm{j}$ & 6.511 & $53.70 \mathrm{j}$ & $8.44 \mathrm{e}$ & $241.19 \mathrm{k}$ & 309.841 \\
\hline & 250 & $6.44 \mathrm{j}$ & $54.19 \mathrm{~h}$ & $7.77 \mathrm{f}$ & $306.91 \mathrm{f}$ & $375.31 \mathrm{~g}$ & $6.82 \mathrm{k}$ & $55.78 \mathrm{i}$ & $8.24 \mathrm{~g}$ & $308.59 \mathrm{~g}$ & $379.43 \mathrm{i}$ \\
\hline & 500 & $6.71 \mathrm{i}$ & $57.05 \mathrm{~g}$ & $7.92 \mathrm{e}$ & $326.46 \mathrm{~d}$ & $398.14 d$ & $7.05 \mathrm{j}$ & $56.01 \mathrm{i}$ & $8.30 \mathrm{f}$ & $324.58 \mathrm{e}$ & $395.94 \mathrm{~d}$ \\
\hline & 1000 & $8.15 \mathrm{~h}$ & $59.92 \mathrm{f}$ & $8.92 \mathrm{c}$ & $328.74 \mathrm{~cd}$ & $405.73 \mathrm{e}$ & $8.55 \mathrm{i}$ & $57.24 \mathrm{~h}$ & $9.43 \mathrm{~b}$ & $329.96 \mathrm{~d}$ & $405.18 \mathrm{f}$ \\
\hline \multirow{4}{*}{$\mathrm{P}_{2}$} & 0 & $9.16 \mathrm{~g}$ & $60.87 \mathrm{e}$ & $7.59 \mathrm{~h}$ & $257.31 \mathrm{i}$ & $334.93 \mathrm{i}$ & $9.53 \mathrm{~h}$ & $57.59 \mathrm{gh}$ & $7.95 \mathrm{i}$ & $259.65 \mathrm{j}$ & $334.72 \mathrm{k}$ \\
\hline & 250 & $9.80 \mathrm{f}$ & $60.20 \mathrm{f}$ & $8.12 \mathrm{~d}$ & $330.89 \mathrm{c}$ & $409.01 \mathrm{e}$ & $10.27 \mathrm{~g}$ & $58.03 \mathrm{~g}$ & $8.57 \mathrm{~d}$ & $336.47 \mathrm{c}$ & $413.34 \mathrm{e}$ \\
\hline & 500 & $10.57 \mathrm{e}$ & $66.83 \mathrm{~d}$ & $9.02 \mathrm{~b}$ & $317.65 \mathrm{e}$ & $404.07 \mathrm{f}$ & $11.07 \mathrm{f}$ & $67.61 \mathrm{f}$ & $9.36 \mathrm{c}$ & $320.51 \mathrm{f}$ & $408.55 \mathrm{~g}$ \\
\hline & 1000 & $10.96 \mathrm{~d}$ & $69.80 \mathrm{c}$ & $9.30 \mathrm{a}$ & $356.45 \mathrm{a}$ & $446.51 \mathrm{~b}$ & $11.43 \mathrm{e}$ & $70.94 \mathrm{e}$ & $9.82 \mathrm{a}$ & $360.16 \mathrm{a}$ & $452.35 \mathrm{c}$ \\
\hline
\end{tabular}

y. Values marked with the same letter (s) are statistically similar using Revised LSD test at $\mathrm{p}=0.05$. Uppercase letter (s) indicate differences between main effects, and lowercase letter(s) indicate differences within interaction of each character.

${ }^{\mathbf{Z}}$ Pruning treatments: $\mathbf{P}_{\mathbf{0}}=$ without pruning (Spanish system) and $\mathbf{P}_{\mathbf{1}}=$ two stems on each plant and $\mathbf{P}_{\mathbf{2}}=$ three stems on each plant

\section{References}

AL-Aghabary, K.; Z. Zhu.; and Q. H. Shi. 2004. Influence of silicon supply on chlorophyll content, chlorophyll fluorescence, and antioxidative enzyme activities in tomato plants under salt stress. Journal of plant nutrition 27 : 2101-2115.

Allen, R.G; L. S, Pereira. D, Raes. and M, Smith. 1998. Crop Evapotranspiration -Guidelines for Computing Crop Water Requirements, pp:
104-114. FAO Irrigation and drainage paper No. 56. FAO Rome, Italy.

Alsadon, A.; M.Wahb-Allah; H. Abdel-Razzak, and A.Ibrahim. 2013. Effects of pruning systems on growth, fruit yield and quality traits of three greenhouse-grown bell pepper (Capsicum annuum L.) cultivars. AJCS 7(9):1309-1316.

Awalin, S., M. Shahjahan, A. Chandra Roy, A. Akter and M. Humayun Kabir.2017.Response of Bell Pepper (Capsicum annuum) to Foliar 
Feeding with Micronutrients and Shoot Pruning. J. Agric. Eco. Res. Int.11(3): 1-8

Cebula, S. 1995. Optimization of plant and shoot spacing in greenhouse production of sweet pepper. Acta Horticulturae 412: 321- 328.

Chatzoulakis, K. and N. Drosos. 1997. Water requirements of greenhouse grown pepper under drip irrigation. Acta Hort. 449: $175-180$.

Dasgan, H. Y. And K. Abak.2003. Effects of Plant Density and Number of Shoots on Yield and Fruit Characteristics of Peppers Grown in Glasshouses. Turk J Agric . 27: 29-35.

Efimova, G. V. and S. A. Dokynchan 1986. Anatomo-morphological construction of epidermal tissue of rice leaves and increasing of its protection function under silicon effect. Agric. Biol., 3:57-61.

El-Sayed, .S. F.; H. A. Hassan and S. O. Mahmoud .2015.Effect of Some Soilless CultureTechniques on Sweet Pepper Growth, Production,Leaves Chemical Contents and Water Consumption under Greenhouse Conditions.Middle East Agric. Res. (4): 682-691

Ezzo, M.I., A.A. Glala, H.A.M. Habib and A.A. Helaly. 2010. Response of sweet pepper grown in sandy and clay soil lysimeters to water regimes. American-Eurasian J. Agric. \& Environ. Sci., 8 (1): 18-26, 2010.

FAO .( 2015). land and water devision report crops water information : pepper.

Fernand, F.; N. Marcussi.; R, Lyra; V. Bôas.; L.J. G.de .Godoy and R. Goto.2004. Macronutrient accumulation and portioning in fertigated sweet pepper plants. Sci. Agric. (Piracicaba,Braz.). 61(1):62-68.

Gomez, C. A. and A. A. Gomez. 1983. Statistical Procedures for Agricultural Research $\left(2_{n d}\right)$ edition .An International Rice Research Institute Book.A wiley-Interscience.

Hanafy Ahmed ; A .H.,Harb ; E.E. Higazy M.A., and H MorganSh. 2008: Effect of silicon and boron foliar application on wheat plants grown under saline soil conditions. Int. J. Agri. Res. 3 (1): 1-26.

Hattori, T.; S. Inanaga.; H. Araki.; A.N P. S. Morita.; M. Luxova and A. Lux.2005. Application of silicon enhanced drought tolerance in Sorghum bicolor. Plant Physi123: 459-466.

Hedge, D.M., 1987. Growth analysis of bell pepper (Capsicum annuum L.) in relation to soil moisture and nitrogen fertilization. Scient. Hort., 33: 179- 187 .

Hipps,

N.A., M.J. Davies, J.M. Dunn, H. Griffiths, and C.J. Atkinson. 2014.Effects of two contrasting canopy manipulations on growth and water use of London plane (Platanus $\mathrm{x}$ acerifolia) trees. Plant Soil, 382 , pp. 61-74.
Jovicich, E., D. J Cantliffe,. and G. J Hochmuth,. 1999. Plant density and shoot pruning on yield and quality of a summer greenhouse sweet pepper crop in North central Florida. p. 184190. In K.D. Batal (ed.) $28^{\text {th }}$ National Agricultural Plastics Congress. Proc. Amer. Soc. Plasticulture, Tallahassee, FL, May 19- 22. ASP, State College, PA.

Katerji; M., M Mastrorilli, A Hamdy, 1993. Effects of water stress at different growth stages on pepper yield. Acta Hort. 335, 165-171.

Kirnak H; C Kaya, Ismail TAS and D. Higgs.2001.The influence of water deficit on vegetative growth, physiology, fruit yield and quality in eggplants. Bulg. J. Plant Physiol., 27(3-4), 34-46.

Maboko ,.M. M.; C. P. Du Plooy and S. Chiloane.2012. Effect of plant population stem and flower pruning on hydroponically grown sweet pepper in a shade net structure. African Agric. Res. 7(11): 742-1748.

Maniutiu, D., R Sima., A. S Apahide., M Apahidean. and D Ficior. 2010. The influence of plant density and shoot pruning on yield of bell pepper cultivated in plastic tunnel. Bull. UASVM Hort 67(1): 259-263

Nielsen, T.H. and B. Veierskov, 1988. Distribution of dry matter in sweet pepper plants (Capsicum annuum L.) during the juvenile and generative growth phases. Sci. Hortic., 35: 179-187.

Page, A. L., R. H. Miller, and D. R. Keeney. 1982. Methods of soil analysis, chemical and microbiological properties, part2, 2nd ed. ASASSSA, Madison, Wisc., USA.

Pereira, HS; G.C Vitti.and GH. Korndörfer.2003. Comportamento de diferentesfontes de silício no solo e nacultura do tomateiro. RevistaBrasileira de Ciência de Solo 27: 101-108.

Qassim, A. and B. Ashcroft, 2002. Estimating Vegetable Crop Water use with MoistureAccounting Method \# AG1192, DPI Victoria. Available at: http://www.dpi.vic.gov.au/agriculture/horticultur e/vegetables/vegetable-growing-andmanagement/estimating-vegetable-crop-wateruse. (Accessed: October 2002).

Razmi, Z. and A. A Ghaemi,. 2011. Crop and soil water stress coefficients of tomato in the glass greenhouse conditions. J. Sci. Technol. Greenhouse Culture.2: 87.

Resh, H.M., 1996. Hydroponic food production, $5^{\text {th }}$ edn, Woodridge Press Publ. Co., Santa Barbara, Califonia.

Ryan, J.G., G. Estefan, A. Rashid .2007. Soil-Plant-Analysis Soil and Plant Analysis Laboratory Manual.Publisher: International Center for Agricultural Research in the Dry Areas (ICARDA), Aleppo, Syria. 
Smittle, D. A.; W. L. Dickens and J. R. Stansel.1994. Irrigation Regimes Affect Yield and Water Use by Bell Pepper. J. AMER. SOC. HORT. SCI. 119(5):936-939.

Thakur, O.; V. Kumar and J. Singh .2018. A Review on Advances in Pruning to Vegetable Crops. Int.J.Curr.Microbiol.App.Sci 7(2): 35563565.

Vamez, C. E; A Alvino, V Magliulo, and Steduto, P., 1992. Pepper response to mild conditions of combined soil water and salinity stress. Adv. Hort. Sci., 6:3-10.
Zende UM. Investigation on production techniques in capsicum under protected cultivation. M. Sc. degree. College of Agriculture, Dharwad, University of Agricultura Sciences Dharwad; 2008.

Zhu Z.J.; G.Q. Wei.; J .Li. Q. Q .Qian; and J. Q. Yu. 2004. Silicon alleviates salt stress and increases antioxidant enzymes activity in leaves of salt-stressed cucumber (Cucumis sativus L.). Plant Sci.167: 527-533.

\title{
الملخص العربي
}

\section{تأثثر الأجهاد المائي ونظام التقليم وسيليكات البوتاسيوم علي إنتاج الكتلة الجافة النباتات الفلفل النامية في أرض جيرية تحت الصوب}

\author{
حماده محمد قطب- حجازى حسن حجازى- إبر اهيم محمد غنيم- مصطفى نبوي فليفيل \\ قسم الخضر - كلية الزر اعة- جامعة الأسكندرية
}

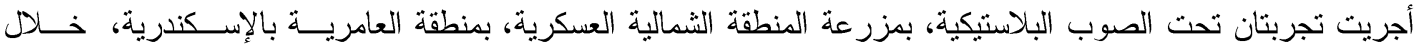

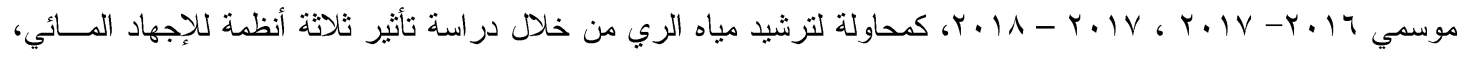

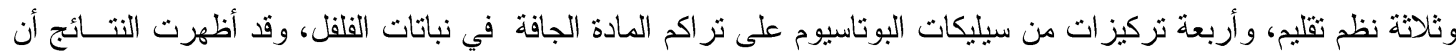

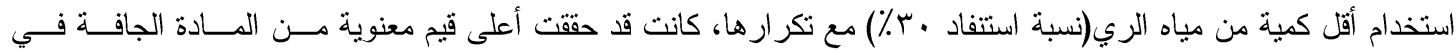

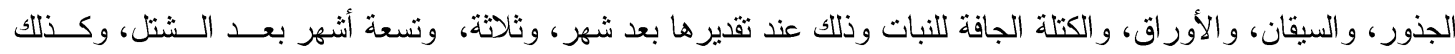

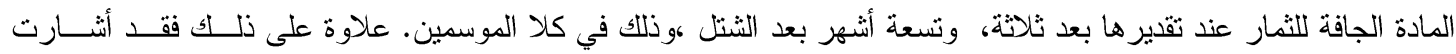

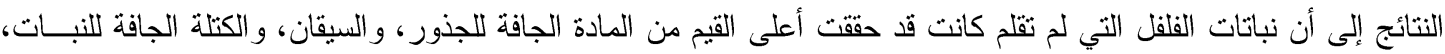

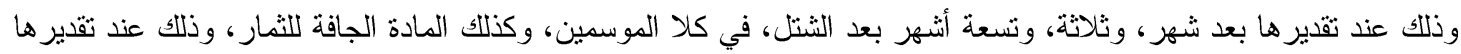

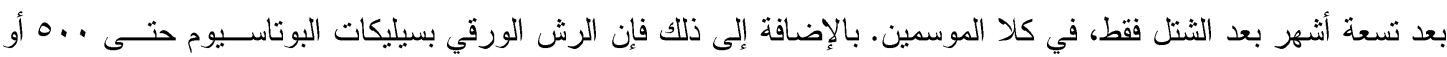

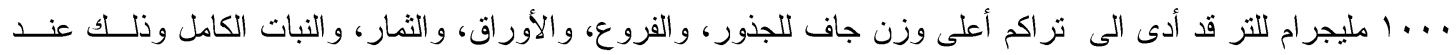

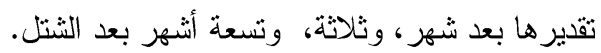

أوضحت نتائج الثأثير المتداخل بين معاملات الاجهاد المائي ونظم التقليم، أن نباتات الفلفل غبر المقلمة، أو التي قلمـــت

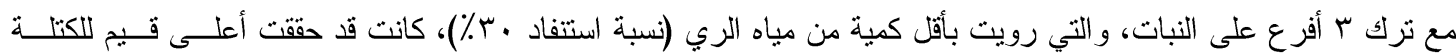

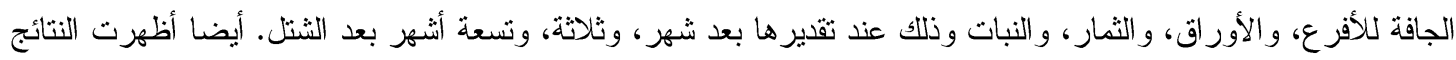

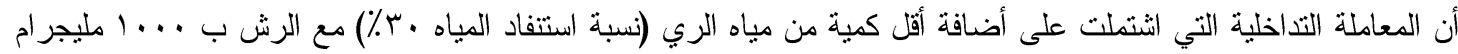

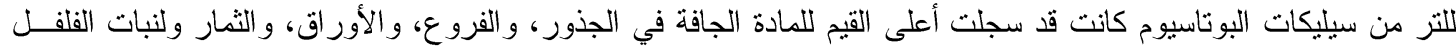

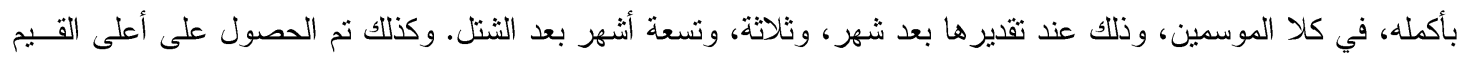

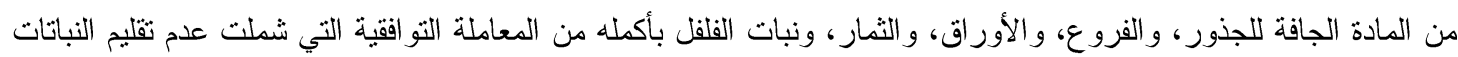

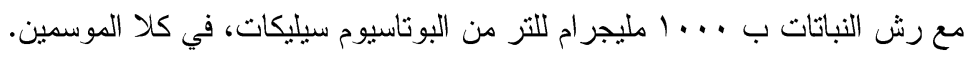

